Article

\title{
Global Amphibian Extinction Risk Assessment for the Panzootic Chytrid Fungus
}

\author{
Dennis Rödder ${ }^{1,2, *}$, Jos Kielgast ${ }^{1,3}$, Jon Bielby ${ }^{4,5}$, Sebastian Schmidtlein ${ }^{6}$, Jaime Bosch ${ }^{7}$, \\ Trenton W.J. Garner ${ }^{4}$, Michael Veith ${ }^{1}$, Susan Walker ${ }^{8}$, Matthew C. Fisher ${ }^{8}$ and \\ Stefan Lötters 1
}

1 Department of Biogeography, Trier University, Am Wissenschaftspark 25-27, D-54296 Trier, Germany; E-Mails: joskielgast@hotmail.com (J.K.); veith@uni-trier.de (M.V.); loetters@uni-trier.de (S.L.)

2 Zoologisches Forschungsmuseum Alexander Koenig, Adenauerallee 160, D-53113 Bonn, Germany

3 Department of Biology, Copenhagen University, Universitetsparken 15, DK-2100 Copenhagen, Denmark

4 Institute of Zoology, Zoological Society of London, Regent's Park, London, NW1 4RY, UK; E-Mails: bielby04@imperial.ac.uk (J.B.); trent.garner@ioz.ac.uk (T.W.J.G.)

5 Department of Biology, Imperial College London, Silwood Park Campus, Ascot Berkshire SL5 7PY, UK

6 Department of Geography, Bonn University, Meckenheimer Allee 166, D-53115 Bonn, Germany; E-Mail: s.schmidtlein@uni-bonn.de (S.S.)

7 Museo Nacional de Ciencias Naturales, Calle José Gutiérrez Abascal 2, E-28006 Madrid, Spain; E-Mail: bosch@mncn.csic.es (J.B.)

8 Department of Infectious Disease Epidemiology, Imperial College London, Silwood Park Campus, Ascot Berkshire SL5 7PY, UK; E-Mails: susan.walker@imperial.ac.uk (S.W.); matthew.fisher@imperial.ac.uk (M.C.F.)

* Author to whom correspondence should be addressed; E-Mail: roedder@uni-trier.de;

Tel.: +49-651-201-4617; Fax: +49-651-201-3851.

Received: 30 July 2009 / Accepted: 7 September 2009 / Published: 11 September 2009

\begin{abstract}
Species are being lost at increasing rates due to anthropogenic effects, leading to the recognition that we are witnessing the onset of a sixth mass extinction. Emerging infectious disease has been shown to increase species loss and any attempts to reduce extinction rates need to squarely confront this challenge. Here, we develop a procedure for identifying amphibian species that are most at risk from the effects of chytridiomycosis by
\end{abstract}


combining spatial analyses of key host life-history variables with the pathogen's predicted distribution. We apply our rule set to the known global diversity of amphibians in order to prioritize species that are most at risk of loss from disease emergence. This risk assessment shows where limited conservation funds are best deployed in order to prevent further loss of species by enabling ex situ amphibian salvage operations and focusing any potential disease mitigation projects.

Keywords: amphibians; Batrachochytrium dendrobatidis; chytridiomycosis; Maxent; Species Distribution Model

\section{Introduction}

The IUCN Red List of Threatened Species reports one third of the about 6,500 extant amphibian species as threatened with extinction [1, for species list see ESI1]. Chytridiomycosis, a disease caused by the amphibian chytrid fungus, Batrachochytrium dendrobatidis $(B d)$, plays a decisive role in this global biodiversity crisis [1-6] by driving rapid declines and species extinctions in pristine protected areas. The balance of evidence shows that $B d$ is spreading globally and, in response, this pathogen has been included as a notifiable disease in the Aquatic Animal Health Code of the World Organization for Animal Health (OIE) (Article 2.4.1.2; www.oie.int/fr/normes/fcode/fr_index.htm; latest access 8 July 2009).

An IUCN 'Amphibian Conservation Action Plan' has been developed [3,4] with its goal being the prevention of further loss of global amphibian biodiversity. This plan states that short-term ex situ breeding is the primary available conservation strategy for species under immediate threat from $B d$ to prevent further dramatic amphibian species loss owing to this panzootic. Antifungal bacteria reducing susceptibility of amphibians to $B d$ in nature may provide an additional solution to solve the amphibian crisis [7]. Beyond this, any attempt to limit further spread of the pathogen requires intimate knowledge of the current distribution of $B d$ and identification of areas and amphibian species assemblages not currently affected by chytridiomycosis. There is a pressing need for tools to prioritize candidate species for targeted population monitoring, ex situ breeding as well as other treatments, to identify critical areas for the implementation of measures to limit the spread of the pathogen and, when possible, target disease mitigation.

Infection by $B d$ is expected to be particularly sensitive to environmental influences because the pathogen exclusively occurs in ectothermic hosts which are physiologically affected by ambient conditions [8]. Furthermore, the pathogen is known to be particularly temperature and moisture dependent [e.g., 9,10]. The in vitro growth optimum of $B d$ is at $17-25^{\circ} \mathrm{C}$, whereas temperatures higher than $29{ }^{\circ} \mathrm{C}$, freezing and desiccation are lethal [11], findings that are supported by observations in the field [12-16]. Hence, the geographic extent of $B d$ 's climatic niche can be readily assessed by Species Distribution Models (SDMs). These models give a prediction of potential distributions of species derived from their associated environmental parameters. In the case of pathogens, such models can provide predictions on impending epizootics in uninfected regions [e.g., 17,18]. 
Herein we undertake a worldwide risk assessment for the potential impact of $B d$ with the goal to identify amphibian species that are most at risk of future declines as a result of $B d$ invasion and infection. We did so by combining known amphibian species ranges with a prediction of the distribution of $B d$ based on a SDM integrated with the biological characteristics of host susceptibility.

\section{Material and Methods}

\subsection{Prediction of Bd Distribution}

Climate information for $B d$ SDM building was obtained from Worldclim, version 1.4 [19], which is based on weather conditions recorded between 1950 and 2000 at spatial resolution of about $1 \times 1 \mathrm{~km}^{2}$. It was created by interpolation using a thin-plate smoothing spline of observed climate at weather stations using latitude, longitude and elevation as independent variables [20]. The climate data set was obtained from the DIVA-GIS homepage (www.diva-gis.org; downloaded 15 May 2007), i.e., 36 monthly mean variables (each minimum and maximum temperature and precipitation, respectively). Based on these we calculated six 'bioclimate' variables for further processing with DIVA-GIS 5.4 [21]: 'annual mean temperature', 'maximum temperature of the warmest month', 'minimum temperature of the coldest month', 'annual precipitation', 'precipitation of the wettest month' and 'precipitation of the driest month'. Since it can be expected that $B d$ zoospores are able to survive in unfrozen microhabitat, water or on hosts during winter air freezing [11], subzero values in the 'minimum temperature of the coldest month' grids were pooled and set to $0{ }^{\circ} \mathrm{C}$. More 'bioclimate' variables than the six used here can be obtained from Worldclim. However, to avoid model 'overfitting' [22] and multicollinearity of predictors, we restricted our study to the six 'bioclimate' variables mentioned which can be considered as biologically relevant parameters to $B d[10,11,14,16]$. Also, these variables have been suggested to perform well in SDMs [23-25] including those for $B d$ [26]. We obtained 365 globally scattered $B d$ records (latitude/longitude) from www.spatialepidemiology.net/bd/ (accessed 15 August 2008). Records posted on this webpage were compiled from numerous scientific publications (a detailed list of references is also posted). $B d$ records were not randomly distributed over the world (Figure 1A), leaving the problem of possible sample selection bias which may violate SDM assumptions [27]. To account for this, we extracted all 'bioclimatic' values at $B d$ records and performed a cluster analysis based on Euclidean distances, whereby resulting classes were blunted at a threshold leaving 200 classes. Only one record per class was used for further processing. This method reduces the amount of duplicate information in the feature space and thereby the impact of samples clumped in geographic space. Calculations were performed with XLSTAT 2008 (Addinsoft, www.xlstat.com; downloaded 1 July 2007).

GARP was used in an earlier model focusing on Bd's potential distribution in the New World [28]. However, advances in SDM methodology [29] and current availability of $B d$ presence records enable modelling at a much finer spatial scale. Herein, Maxent 3.3.1 (www.cs.princeton.edu/ shapire/maxent; downloaded 25 May 2009) was used for Bd SDM calculation and mapping [30,31]. Maxent has been developed within the machine learning community and implements a general purpose algorithm for making predictions and inferences from incomplete information. The Maxent algorithm estimates 
geographic distributions of species from locality point data and random background data by finding the maximum entropy distribution [30]. Ideally, the area from which background data is obtained reflects those regions accessible to the target species [32]. Therefore, we restricted the background samples to areas from which $B d$ was detected in the wild. Areas with climate conditions not analogous to those represented by background data may lead to uncertainties in model predictions. Maxent automatically allows an identification of the degree of uncertainty when projecting models ('clamping'). In our SDM, the degree of 'clamping' was removed from the model prediction using the 'fade by clamping' option. In numerous comparative studies, Maxent has achieved better results than other presence only methods [summarized by 29,33].

It has been suggested that ensemble model predictions may enhance the reliability and robustness of SDM results [34]. Therefore, we computed 100 models each trained with randomly chosen $75 \%$ of the 200 records for model training and subsequently integrated all results into a map indicating the average Maxent value per grid cell. The remaining $25 \%$ of the records were used for model evaluation through calculation of the Area Under the Curve (AUC) in Receiver Operating Characteristic curves [35], a threshold-independent index widely used in ecological modelling [35,36]. In ROCs, the sensitivity values, the true-positive fraction against 1-specificity and the false positive fraction for all available probability thresholds are plotted [36,37]. AUC values may range from 0.5 (random accuracy) to 1.0 (perfect discrimination). We received 'good' to 'excellent', following previously given definitions [37], AUC values, suggesting a high quality of our SDM output: mean $\mathrm{AUC}_{\text {training data }}=0.937$; mean $\mathrm{AUC}_{\text {test data }}=0.910$ (Figure 1A). Maxent allows to trace the relative contribution of each variable to the model. Herein, the 'annual mean temperature' had the highest explanatory power, followed by the 'maximum temperature of the warmest month' (Figure 1B). This pattern was consistent in all 100 models computed.

Figure 1. Variation of $\mathrm{AUC}_{\text {training }}$ and $\mathrm{AUC}_{\text {test }}(\mathrm{A})$, and variable contribution (B), minimum and 10 percentile training presence $(\mathrm{C})$ in 100 Maxent models. Abbreviations are: Bio1 = 'annual mean temperature'; Bio5 = 'maximum temperature of the warmest month'; Bio6 = 'minimum temperature of the coldest month'; Bio12 = 'mean annual precipitation'; Bio13 = 'maximum precipitation of the wettest month'; Bio14 = 'minimum precipitation of the driest month'. In boxplots, the minimum and maximum values are indicated as blue dots, 95\% confidence intervals as short horizontal bars; the $1^{\text {st }}$ and $3^{\text {rd }}$ quartiles and the median are indicated as broad horizontal bars and means as red crosses.
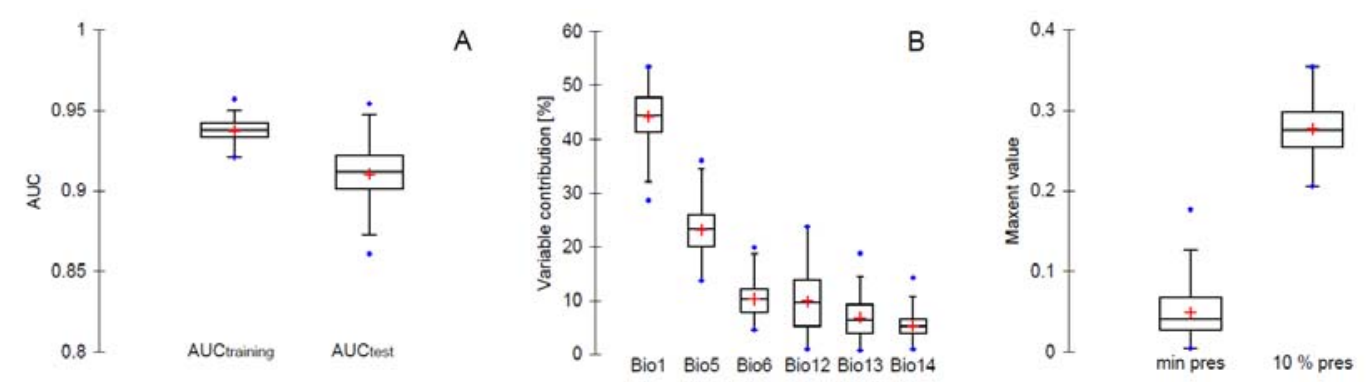
The logistic output of Maxent chosen by us is a continuous, linear scaled map which allows fine distinctions to be made between the modelled probability of habitat suitability for $B d$. Generally, the higher a logistic Maxent value the better the prediction and therefore the climatic suitability for a species under study. It has been proposed that this relationship can be directly related to a species' maximum possible abundance [38]. Maxent calculates several threshold values at each run and values exceeding them may be interpreted as reasonable approximation of —in this case- $B d$ 's potential distribution pending on the question at hand. We used the minimum training presence (mean $=0.049$ ) as a strict threshold and the 10 percentile training presence (mean $=0.277$; Figure $1 \mathrm{C}$ ) as a more liberal threshold as suggested by Phillips et al. [30]. In general, the mean Maxent value at the input records is typically 0.5 [30,31], which was therefore selected as third threshold as recommended by Liu et al. [39]. Furthermore, the uppermost $25 \%$ of the logistic value was chosen as fourth threshold (logistic Maxent value of 0.75).

\subsection{Identification of the Most Threatened Species}

Geographic ranges of 6,156 amphibian species of all three orders were adopted from the IUCN Red List of Threatened Species, as categorized during the former IUCN/Conservation International/NatureServe 'Global Amphibian Assessment' ([1], www.natureserve.org/getdata/amphibianmaps.jsp; accessed 7 July 2009; see ESI1, whereby taxonomy follows [40,41]). In order to assess $B d$ suitability within the geographic range of all amphibian species, we performed an overlay analysis of our $B d$ world map obtained from the SDM and the distributions of the 6,156 amphibian species. Higher logistic Maxent values at a given site are associated with a higher climatic suitability and most likely a higher maximum abundance for $B d$ [30,38]. Since the mean minimum training presence and the lowest 10 percentile training presences in our model were 0.049 and 0.227 (Figure 1C) and in accordance with previous studies [39], we regard these as minimum thresholds for the environmental suitability to $B d$. We calculated the total geographic range encompassed by each amphibian species and quantified the fraction suitable for $B d$ at four Maxent thresholds (>0.049, >0.227, >0.50, >0.75; see ESI1). Computations were performed with DIVA-GIS 5.4 and ESRI ArcMap 9.2.

\subsection{Bd Risk Factor for Anuran Amphibians}

In an approach to identify anuran species (from a total of 3,976) which exhibit highest probabilities of $B d$-related decline or extinction, biological and life history information of $B d$ infected species showing rapid declines was used as explanative variables in a previously published study [42]. Life history information comprised the degree of aquatic life-stage, the mean snout-vent length and the mean clutch size and geographic range size. Representative environmental values for each species were added using spatial datasets of altitude, annual actual evapotranspiration, net primary productivity, isothermality (a measure of annual temperature consistency), maximum temperature of the warmest month, precipitation seasonality, precipitation in the driest quarter and human population density [43-45]. For model building, so called Generalized Linear Models specifying the link function as either 'logit' or complementary 'log-log' were applied, whereby the link with the lowest residual 
deviance was preferred [42]. Expected effects of strong phylogenetic signals were removed using generalised estimating equations and Holm-Bonferroni corrections were made to account for Type I errors. According to the most predictive multi-predictor model (brier score $=0.06$ ), species with aquatic life stages occupying small geographic ranges at high altitudes were most susceptible for $B d$ related declines. This final model was projected onto a larger data set, whereby a standardized value between 0 and 1 for each species was calculated, hereafter termed 'Biotic Index' (BI) (compare species list in ESI1 and see [42] for elaborate description of methods).

In order to generate a $B d$ 'Risk Factor' (RF) for anurans, we combined BI and the results of our quantification of species' distributions with high suitability to $B d$ (Maxent value $>0.50$, which is the mean score at the $B d$ records used for model building which was suggested as a suitable threshold [39]; ESI1) as:

$$
R F=\frac{(B I * 100) * \text { area }_{b d}}{10,000}
$$

where area $_{b d}=$ the percentage of a species' distribution $>0.50 B d$ suitability. RF equally weights $B I$ and area $_{b d}$ ranges between 0 and 1 , whereby higher values reflect a higher threat balancing equally the fraction of the species area suitable to $B d$ and the BI.

\section{Results and Discussion}

\subsection{Prediction of Bd Distribution}

Our SDM suggests that highest suitability for $B d$ occurs in temperate and subtropical regions of both hemispheres, often near coasts; in the tropics, for instance, montane regions are identified to show a high suitability for $B d$ (Figure 2A). The potential distribution of $B d$ suggested by our SDM generally resembles that obtained through an earlier GARP approach [28] with fine scale patterns better depicted in our approach.

The currently known distribution of $B d$ records in the world is patchy (Figure 2A). Even when some of these gaps may be the result of limited collection efforts for $B d$, as in Western Europe [4], it is remarkable that there are island-like high risk regions in which chytridiomycosis and its effects have not yet been observed [1,4]. These include the Ethiopian Highlands, eastern Madagascar, the southern versant of the Himalaya, China's Yunnan province and considerable portions of tropical Asia (Figure 2A). The importance of these highly suitable locations being apparently free of the effects of the chytrid fungus is magnified considering that these regions harbour high levels of amphibian species richness and endemism (Figure 2B).

Evidence for extraordinary dispersal speed of $B d$ has been recorded in some regions [9] and apparently anthropogenic dissemination, especially through the international trade, has contributed decisively to the speed and extent of $B d$ 's spread [46,47]. Therefore, biosecurity measures and baseline surveys should be initiated at those areas highlighted through our analysis. 
Figure 2. (A) Worldwide potential distribution of the amphibian chytrid fungus (Bd) and 200 out of 365 records (black dots) of this pathogen (see methods). The map is derived from a Maxent SDM projected into geographic space based on six 'bioclimate' variables. Warmer colors are associated with higher Maxent values suggesting higher suitability for $B d$, whereas grey areas are below the minimum training threshold and therefore considered to be unsuitable. This is equivalent to higher risk of invasion in regions from which $B d$ is currently absent. (B) Overlay highlighting worldwide regions of both high $B d$ suitability and high amphibian species richness. Warmer colors suggest higher overlap of $B d$ suitability (based on our SDM) and number of known amphibian species (see ESI1). (C) 'Risk Factor' (RF) for anuran amphibian species, calculated by combination of species life history traits linked with $B d$-caused declines [42] and climatic suitability for $B d$ within the species' range (Appendices ESI1, ESI2). Warmer colors equal a higher proportion of species with a high RF per $0.5^{\circ}$ grid cell.

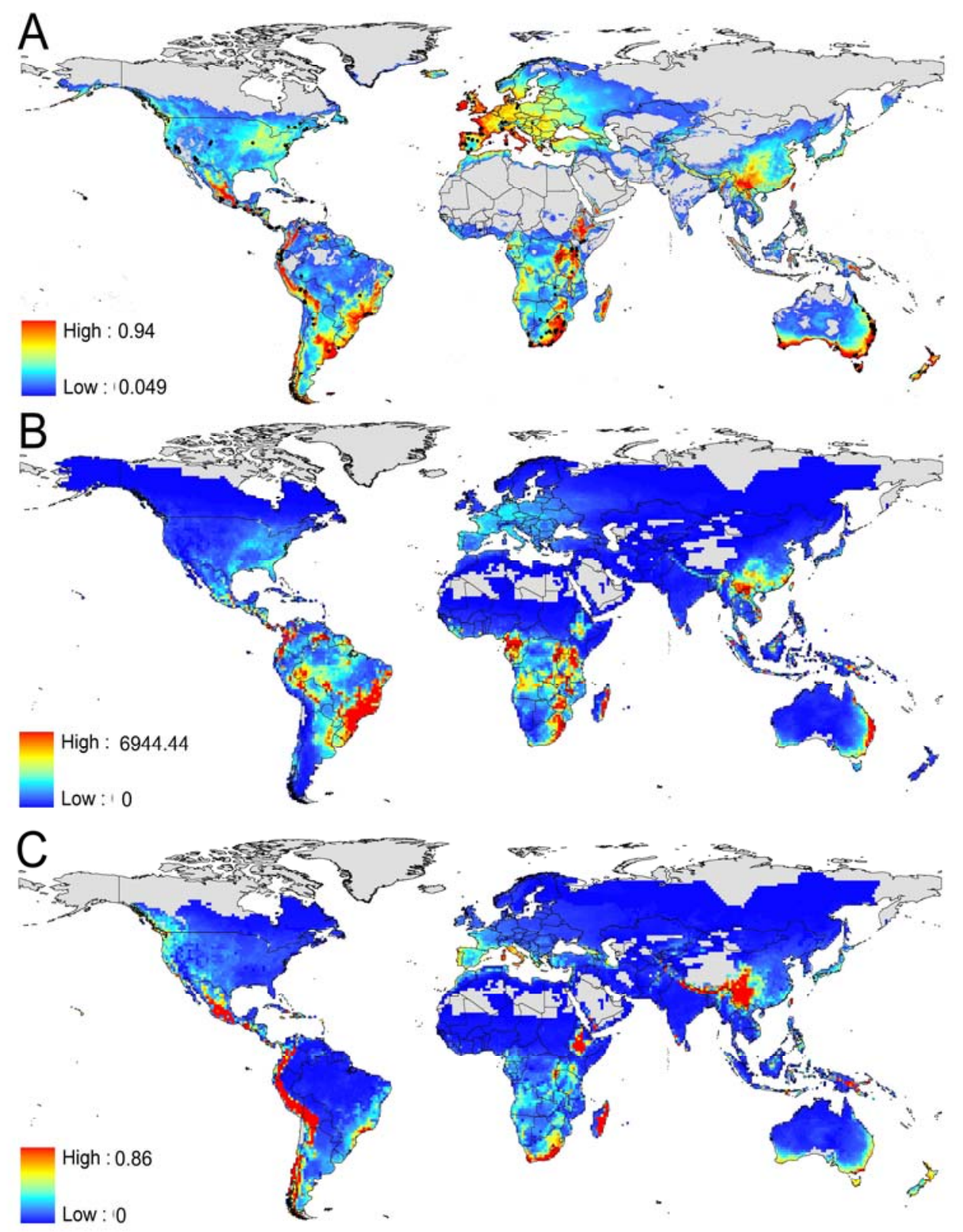




\subsection{Identification of the Most Threatened Species}

The proportion of species within each amphibian order that exhibit a high overlap with areas that are environmentally suitable to $B d$ is summarized in Table 1 (for a detailed species list including results of the presented analysis, IUCN conservation status and $B d$ presence see ESI1). Approximately one sixth of all known amphibian species fall with their total distributions into regions potentially suitable to $B d$ (Maxent value >minimum observed training presence; Figure $1 \mathrm{~A}$ ) and more than $50 \%$ of all species exhibits an overlap of over half of their known geographic range with regions showing high $B d$ suitability. This number drastically increases to almost 6,000 (i.e., roughly all known amphibians) when over half of a species' range overlaps regions with a Maxent value $>0.5$ (Table 1 ).

Table 1. Number of species in the known amphibian orders which are most threatened by $B d$ through range overlap. Suitability for the pathogen is high at different percentages of their known geographic ranges. We here provide species numbers referable to environmentally suitable (minimum observed training presence) or highly suitable to $B d$ (values > 0.5) (Figure 2A). ESI1 provides detailed species-level information.

\begin{tabular}{llll}
\hline & \multicolumn{4}{l}{$\begin{array}{l}\text { Portion of } \\
\text { (>0.5/minimum observed training presence) }\end{array}$} & \multicolumn{2}{c}{ range } & environmentally & suitable \\
& $\mathbf{1 0 0 \%}$ & $\mathbf{7 5 \%}$ & $\mathbf{5 0 \%}$ \\
\hline Caecilians (172 species) & $10 / 90$ & $27 / 132$ & $38 / 138$ \\
Salamanders (551 species) & $129 / 498$ & $195 / 543$ & $226 / 545$ \\
Frogs and toads (5,532 species) & $961 / 3,905$ & $1,756 / 4,953$ & $2,259 / 5,211$ \\
\hline Total (6,142 species) & $1,100 / 4,493$ & $1,978 / 5,628$ & $2,523 / 5,894$ \\
\hline
\end{tabular}

\subsection{Bd Risk Factor for Anuran Amphibians}

Most of the 833 anuran species which by their biology and life history show a high predicted susceptibility to $B d$ [42] occur in regions which at the same time are characterized by high suitability for $B d$ (listed in ESI1). Of these, we identified 379 species in which the entire geographic range is, in terms of climate, of high suitability to $B d$ (Maxent value $>0.5$; for detailed list see ESI2). We consider these amphibians to be the most threatened by the emergence of $B d$. As shown in Figure 2C, they are distributed all over the world including regions from where $B d$ is currently unknown (Figure 2A).

So far, little is known about the current infection or population status of most of the 'Top 379'. Perhaps due to the circumstance that many of them occur in regions from where $B d$ has not been recorded only seven of these species are reported to be infected with $B d$ in nature (list provided in ESI2). We suggest this is the result of limited surveillance for disease rather than the occurrence of healthy populations, as at least 42 species of the 'Top 379' (ESI2) have undergone so called 'rapid enigmatic declines' likely caused by the spread of $B d$ and the effect of chytridiomycosis [1,5]. Generally, the 'Top 379' priority species outlined in ESI2 should be considered as the 'top of the iceberg'. The threshold of RF = 1 used for their identification was perhaps chosen in an arbitrary way since all species with RF $>0$ may be affected in one or the other way. Available conservation funds should be invested for targeted population monitoring, compilation of life history and ecology 
information, and - if necessary — further in situ and ex situ efforts in descending order of RF, since the higher the RF value the higher is the potential threat caused by $B d$.

The importance of emerging infectious diseases and anthropogenic dissemination of pathogens for biodiversity has in recent years been receiving increasing attention especially due to a suite of zoonotic diseases with impact on humans and economically important domestic animals. However, the integration of wildlife diseases in strategies for halting the loss of biodiversity is still remarkably premature $[48,49]$. Of the 379 species identified under high risk of decline due to chytridiomycosis, $40 \%$ are categorized as 'Data Deficient' under the IUCN Red List of Threatened Species, whereas a compelling $94 \%$ of the species with sufficient information for proper assessment are categorized as threatened with extinction. However, it needs to be noted that species with restricted distributions and a combination of ongoing habitat threats would at the same time qualify as threatened based on IUCN's criteria $\mathrm{B}$ and as susceptible for $B d$ related declines according to the $B I$. Herein, we highlight the need to integrate novel approaches in the tool-set of conservation biology to mitigate the threat posed by pathogens.

\subsection{Methodological Considerations}

When interpreting our results, some issues related to the data and methods used herein need to be considered. Information on the distribution of the world's amphibians was adopted via the IUCN Red List of Threatened Species from the former 'Global Amphibian Assessment'. These data provide the most comprehensive and up to information currently available. Range information of each species is based on expert opinions; therefore the polygons describe in most cases the extent of occurrence and sometimes the area of occupancy of each species rather than providing an exact summary of existing populations [see 50]. This may lead to an overestimation of the actually suitable areas in widely occurring species which may not be homogenously distributed throughout their general extent of occurrence (e.g., due to specific habitat requirements). Worldwide, these potential errors may not be homogenously distributed. Before conducting specific management actions, this should be acknowledged. However, since these polygons represent the best information available also used to derive the actual IUCN Red List status of amphibian species, they provide a suitable basis for our assessment.

Methodical inherent uncertainties can be assessed comparing multiple SDMs in ensembles of models providing more robust predictions [34]. In our 100 models combined in the final model we observed rather low standard deviations of predictions per grid cells indicating low model variability and a generally good predictive ability (Figure 3). SDMs rely on specific assumptions including that environmental conditions are range limiting and that the range of the target species is in equilibrium with climate [51]. Looking at the requirements of $B d$ regarding certain temperature and humidity conditions proven by both laboratory and field studies (see above), as well as the nearly world-wide distribution of $B d$, these assumptions appear to be fairly met. Furthermore, SDMs commonly ignore biotic interactions which may lead to an exclusion of the modeled species from certain areas [52]. Regarding $B d$, the most obvious biotic interaction include the pathogens' relationship to amphibians. 
However, since nearly all areas predicted to be suitable for $B d$ harbor at least one amphibian species, this requirement appears also to be fulfilled.

Figure 3. Standard deviation (SD, upper panel) per grid cell of all of the 100 Maxent models used for the ensemble prediction (Figure 2A). In the vast majority of grid cells, the $\mathrm{SD}$ is rather low $<0.05$ (lower panel).

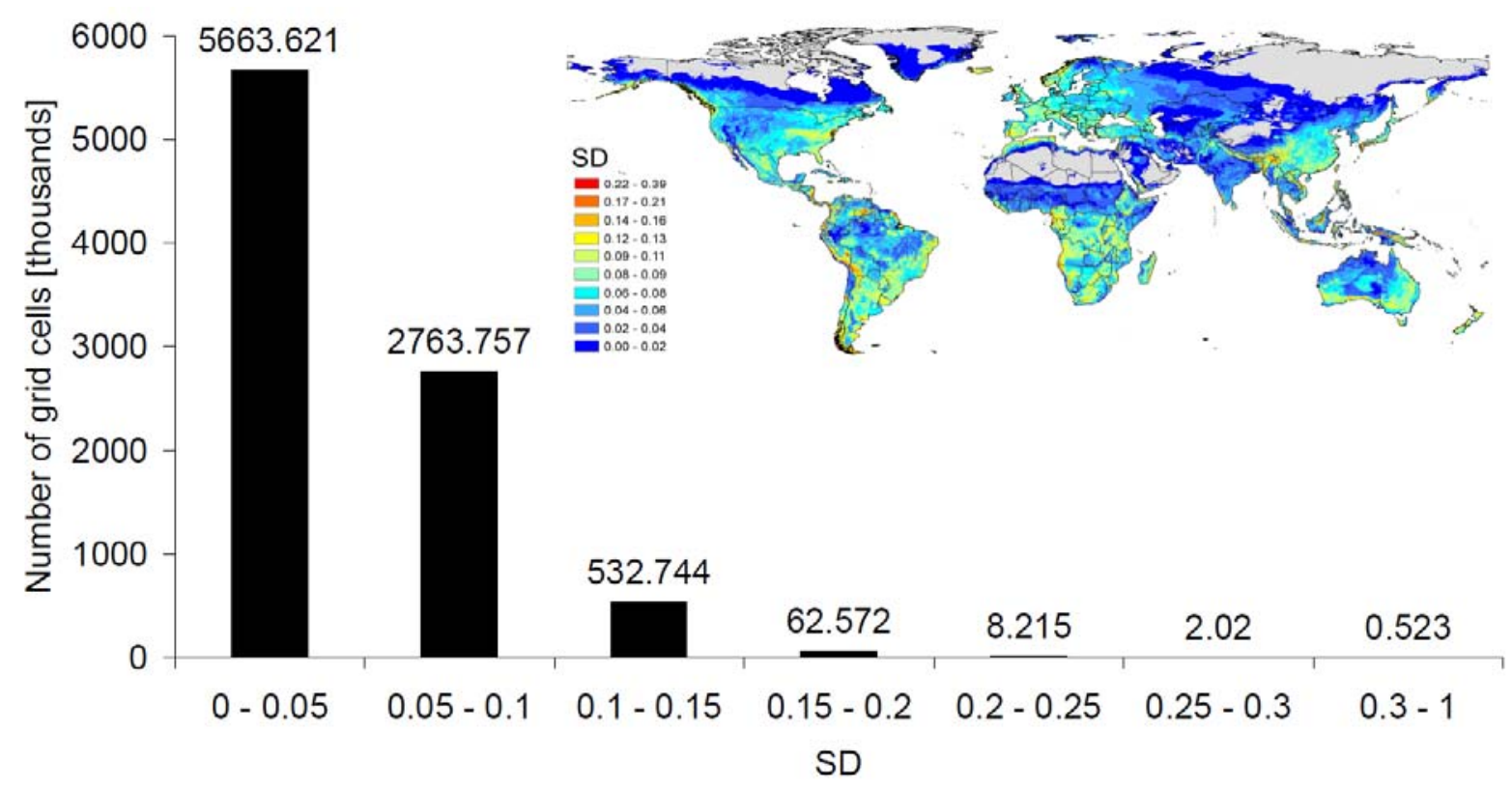

\section{Conclusions}

This research has shown that prioritization of species based on predictive modelling is possible given our knowledge of the distribution and drivers of a largely cryptic wildlife disease. Given that such diseases are being recognized in other wildlife species [e.g., 49,53,54], such predictive approaches are going to be increasingly necessary to manage the global species rescue that will be necessary if we are to not lose an irreplaceable sector of our biodiversity.

\section{Acknowledgements}

We are grateful to the numerous helpful comments of three anonymous reviewers which helped to improve this paper. The work of the first author was funded by the 'Graduiertenförderung des Landes Nordrhein-Westfalen'.

\section{Supplementary Material}

The following supplementary material is available at http://dx.doi.org/10.3390/d1010052.

ESM 1: Table. Overview of amphibian species conservation status as listed by the IUCN Red List status and their geographic range size (downloaded 7 July 2009 from www.redlist.org), followed for each species by the portion of its geographic range suitable to $B d$ and, if applicable, the 'Biotic Index' 
(BI) and the 'Risk Factor' (RF) estimated in this paper. Furthermore species that were encompassed under 'rapid enigmatic declines' in the Global Amphibian Assessment 2004 (updated under the IUCN Red List 2009) and species in which $B d$ has been reported in the literature are pointed out.

ESM 2: List of most threatened species. The 379 species identified as most threatened through $B d$, i.e. $\mathrm{RF}=1.0(\mathrm{BI}=1.0$ and Maxent values $>0.50$ at $100 \%$ of their geographic range, see text). The 216 species listed as 'threatened with extinction' (i.e. IUCN Red List categories 'Vulnerable', 'Endangered' or 'Critically Endangered') are in bold while species that are too poorly known to asses the conservation status (i.e. categorised as 'Data Deficient' in the IUCN Red List) are italicised. A total number of 187 species that are assessed by the IUCN to be declining are marked with asterisks. Species in which $B d$ have been detected [55-58] are underlined. Entries are by family, following the taxonomy used by IUCN in the 2009 assessment [1,ESM 1].

\section{References}

1. Stuart, S.; Chanson, J.S.; Cox, N.A.; Young, B.E.; Rodrigues, A.S.L.; Fischman, D.L.; Waller, R.W. Status and trends of amphibian declines and extinctions worldwide. Science 2004, 306, 1783-1786.

2. Berger, L.; Speare, R.; Daszak, P.; Green, D.E.; Cunningham, A.A.; Goggin, C.L.; Slocombe, R.; Ragan, M.A.; Hyatt, A.D.; McDonald, K.R.; Hines, H.B.; Lips, K.R.; Marantelli, G.; Parkes, H.T. Chytridiomycosis causes amphibian mortality associated with population declines in the rain forests of Australia and Central America. Proc. Natl. Acad. Sci. USA 1998, 95, 9031-9036.

3. Mendelson, J.R., III; Lips, K.R.; Gagliardo, R.W.; Rabb, G.B.; Collins, J.P.; Diffendorfer, J.E.; Daszack, P.; Ibáñez, R.; Zippel, K.C.; Lawson, D.P.; Wright, K.M.; Stuart, S.N.; Gascon, C.; Silva, H.R.; Burrowes, P.A.; Joglar, R.L.; La Marca, E.; Lötters, S.; Perez, L.H.; Weldon, C.; Hyatt, A.; Rodriguez-Mahecha, J.V.; Hunt, S.; Robertson, H.; Lock, B.; Raxworthy, C.J.; Frost, D.R.; Lacy, R.C.; Alfrod, R.A.; Campbell, J.A.; Parra-Olea, G.; Bolaños, F.; Domingo, J.J.C.; Halliday, T.; Murphy, J.B.; Wake, M.H.; Coloma, L.A.; Kuzmin, S.L.; Price, M.S.; Howell, K.M.; Lau, M.; Pethiyagoda, R.; Boone, M.; Lannoo, M.J.; Blaustein, A.R.; Dobson, A.; Griffiths, A.; Crump, M.L.; Wake, D.B.; Brodie, E.D.J. Confronting amphibian declines and extinctions. Science 2006, 313, 48.

4. Gascon, C.; Collins, J.P.; Moore, R.D.; Church, D.R.; McKay, J.E.; Mendelson, J.R., III. Amphibian Conservation Action Plan; IUCN: Gland, Switzerland, 2007.

5. Skerratt, L.F.; Berger, L.; Speare, R.; Cashins, S.; McDonald, K.R.; Phillott, A.D.; Hines, H.B.; Kenyon, N. Spread of chytridiomycosis has caused the rapid global decline and extinction of frogs. EcoHealth 2007, 4, 125-134.

6. Wake, D.B.; Vredenburg, V.T. Are we in the midst of the sixth mass extinction? A review from the world of amphibians. Proc. Natl. Acad. Sci. USA 2008, 105, 11466-11473.

7. Harris, R.N.; Lauer, A.; Simon, M.A.; Banning, J.L.; Alford, R.A. Addition of antifungal skin bacteria to salamanders ameliorates the effects of chytridiomycosis. Dis. Aquat. Org. 2009, 83, 11-16. 
8. Deutsch, C.A.; Tweksbury, J.J.; Huey, R.B.; Sheldon, K.S.; Ghalambor, C.K.; Haak, D.C.; Martin, P.R. Impacts of climate warming on terrestrial ectotherms across latitude. Proc. Natl. Acad. Sci. USA 2008, 105, 6668-6672.

9. Lips, K.R.; Diffendorfer, J.; Mendelson, J.R., III; Sears, M.W. Riding the wave: reconciling the roles of disease and climate change in amphibian declines. PLoS Biol. 2008, 6, 441-454.

10. Woodhams, D.C.; Alford, R.A.; Briggs, C.J.; Johnson, M.; Rollins-Smith, L.A. Life-history trade-offs influence disease in changing climates: strategies of an amphibian pathogen. Ecology 2008, 89, 1627-1639.

11. Piotrowski, J.S.; Annis, S.L.; Longcore, J.E. Physiology of Batrachochytrium dendrobatidis, a chytrid pathogen of amphibians. Mycologia 2004, 96, 9-15.

12. Kriger, K.M.; Hero, J.-M. Large-scale seasonal variation in the prevalence and severity of chytridiomycosis. J. Zool. 2007, 271, 352-359.

13. Kriger, K.M.; Peregolou, F.; Hero, J.-M. Latitudinal variation in the prevalence and intensity of chytrid (Batrachochytrium dendrobatidis) infection in eastern Australia. Conserv. Biol. 2007, 21, 1280-1290.

14. Rödder, D.; Veith, M.; Lötters, S. Environmental gradients explaining prevalence and intensity of infection with the amphibian chytrid fungus: The host's perspective. Anim. Conserv. 2008, 11, 513-517.

15. Woodhams, D.C.; Alford, R.A.; Marantelli, G. Ecology of chytridiomycosis in rainforest stream frog assemblages of tropical Queensland. Conserv. Biol. 2005, 19, 1449-1459.

16. Kielgast, J.; Rödder, D.; Veith, M.; Lötters, S. Widespread occurrence of the amphibian chytrid fungus in Kenya. Animal Cons. 2009, (in press).

17. Blackburn, J.K.; McNyset, K.M.; Curtins, A.; Hugh-Jones, M.E. Modeling the geographic distribution of Bacillus anthracis, the causative agent of Anthrax disease, for the contiguous United States using predictive ecological niche modeling. Am. J. Trop. Med. Hyg. 2007, 77, 1103-1110.

18. Ostfeld, R.S.; Glass, G.E.; Keesing, F. Spatial epidemiology: an emerging (or re-emerging) discipline. TREE 2005, 20, 328-336.

19. Hijmans, R.J.; Cameron, S.E.; Parra, J.L.; Jones, P.G.; Jarvis, A. Very high resolution interpolated climate surfaces for global land areas. Int. J. Climatol. 2005, 25, 1965-1978.

20. Hutchinson, M.F. Anusplin version 4.3. Centre for Resource and Environment Studies. The Australian National University: Canberra, Australia, 2004.

21. Hijmans, R.J.; Cruz, J.M.; Rojas, E.; Guarino, L. Diva-GIS, version 1.4. A Geographic Information System for the Management and Analysis of Genetic Resources Data. Manual. International Potato Center and International Plant Genetic Resources Institute: Lima, Peru, 2001.

22. Heikkinen, R.K.; Luoto, M.; Araújo, M.B.; Virkkala, R.; Thuiller, W.; Sykes, M.T. Methods and uncertainties in bioclimatic envelope modeling under climate change. Progr. Phys. Geogr. 2006, 30, 751-777.

23. Hijmans, R.J.; Graham, C.H. The ability of climate envelope models to predict the effect of climate change on species distributions. Glob. Change Biol. 2006, 12, 2272-2281. 
24. Ficetola, G.F.; Thuiller, W.; Miaud, C. Prediction and validation of the potential global distribution of a problematic alien species-the American bullfrog. Divers. Distrib. 2007, 13, 476-485.

25. Fitzpatrick, M.C.; Weltzin, J.F.; Sanders, N.J.; Dunn, R.R. The biogeography of prediction error: Why does the introduced range of the fire ant over-predict its native range? Glob. Ecol. Biogeogr. 2007, 16, 24-33.

26. Puschendorf, R.; Carnaval, A.C.; Vanderwal, J.; Zumbado-Ulate, H.; Chaves, G.; Bolaños, F.; Alford, R.A. Distribution models for the amphibian chytrid Batrachochytrium dendrobatidis in Costa Rica: proposing climatic refuges as a conservation tool. Divers. Distrib. 2009, 15, 401-408.

27. Dormann, C.F.; McPherson, J.; Araújo, M.B.; Bivand, R.; Bollinger, J.; Carl, G.; Davies, R.G.; Hirzel, A.; Jetz, W.; Kissling, W.D.; Kühn, I.; Ohlemüller, R.; Peres-Neto, P.R.; Reineking, B.; Schröder, B.; Schurr, F.M.; Wilson, R. Methods to account for spatial autocorrelation in the analysis of species distributional data: A review. Ecography 2007, 30, 609-628.

28. Ron, S.R. Predicting the distribution of the amphibian pathogen Batrachochytrium dendrobatidis in the new world. Biotropica 2005, 37, 209-221.

29. Wisz, M.S.; Hijmans, R.J.; Peterson, A.T.; Graham, C.H.; Guisan, A.; NPSDW Group. Effects of sample size on the performance of species distribution models. Divers. Distrib. 2008, 14, 763-773.

30. Phillips, S.J.; Dudík, M. Modelling of species distributions with Maxent: new extensions and comprehensive evaluation. Ecography 2008, 31, 161-175.

31. Phillips, S.J.; Anderson, R.P.; Schapire, R.E. Maximum entropy modeling of species geographic distributions. Ecol. Model. 2006, 190, 231-259.

32. Phillips, S.J. Transferability, sample selection bias and background data in presence-only modelling: a response to Peterson et al. (2007). Ecography 2008, 31, 272-278.

33. Elith, J.; Graham, C.H.; Anderson, R.P.; Dudik, M.; Ferrier, S.; Guisan, A.; Hijmans, R.J.; Huettmann, F.; Leathwick, J.R.; Lehmann, A.; Li, J.; Lohmann, L.G.; Loiselle, B.A.; Manion, G.; Moritz, C.; Nakamura, M.; Nakazawa, Y.; Overton, J.M.M.; Peterson, A.T.; Phillips, S.J.; Richardson, K.; Scachetti-Pereira, R.; Shapire, R.E.; Soberón, J.; Williams, S.; Wisz, M.S.; Zimmermann, N.E. Novel methods improve prediction of species' distributions from occurrence data. Ecography 2006, 29, 129-151.

34. Araújo, M.B.; New, M. Ensemble forecasting of species distributions. TREE 2007, 22, 42-47.

35. Fielding, A.H.; Bell, J.F. A review of methods for the assessment of prediction errors in conservation presence/absence models. Environ. Conserv. 1997, 24, 38-49.

36. Manel, S.; Williams, H.C.; Ormerod, S.J. Evaluating presence-absence models in ecology: The need to account for prevalence. J. Appl. Ecol. 2001, 38, 921-931.

37. Swets, K. Measuring the accuracy of diagnostic systems. Science 1988, 240, 1285-1293.

38. Vanderwal, J.; Shoo, L.P.; Johnson, C.N.; Williams, S.E. Abundance and the environmental niche: environmental suitability estimated from niche models predicts the upper limit of local abundance. Am. Nat. 2009, 174, 282-291.

39. Liu, C.; Pam, M.; Dawson, T.P.; Pearson, R.G. Selecting thresholds of occurrence in the prediction of species distributions. Ecography 2005, 28, 385-393. 
40. Frost, D.R.; Grant, T.; Faivovich, J.; Bain, R.H.; Haas, A.; Haddad, C.F.B.; de Sá, R.O.; Channing, A.; Wilkinson, M.; Donnellan, S.C.; Raxworthy, C.J.; Campbell, J.A.; Blotto, B.L.; Moler, P.; Drewes, R.C.; Nussbaum, R.A.; Lynch, J.D.; Green, M.D.; Wheeler, W.C. The amphibian tree of life. Bull. Am. Mus. Nat. Hist. 2006, 297, 1-370.

41. Grant, T.; Frost, D.R.; Caldwell, J.P.; Gagliardo, R.; Haddad, C.F.B.; Kok, P.J.R.; Means, D.B.; Noonan, B.P.; Schargel, W.E.; Wheeler, W.C. Phylogenetic systematics of dart-poison frogs and their relatives (Amphibia, Athesphatanura, Dendrobatidae). Bull. Am. Mus. Nat. Hist. 2006, 299, 1-262.

42. Bielby, J.; Cooper, N.; Cunningham, A.A.; Garner, T.W.J.; Purvis, A. Predicting susceptibility to rapid declines in the world's frogs. Conserv. Lett. 2008, 1, 82-90.

43. Hijmans, R.J.; Cameron, S.E.; Parra, J.L.; Jones, P.G.; Jarvis, A. Very high resolution interpolated climate surfaces for global land areas. Int. J. Climatol. 2005, 25, 1965-1978.

44. Willmott, C.J.; Kenji, M. Terrestrial Air Temperature and Precipitation: Monthly and Annual Time Series (1950-1999). Available online: http://climate.geog.udel.edu/ climate/html_pages/ README.ghcn_ts2.html (access 8 July 2009).

45. CIESIN. Center for International Earth Science Information Network, Columbia University, New York, NY, USA, 2000; Available online http://www.ciesin.columbia.edu/ download_data.html (access on 8 July 2009).

46. Fisher, M.C.; Garner, T.W.J. The relationship between the emergence of Batrachochytrium dendrobatidis, the international trade in amphibians and introduced amphibian species. Fungal Biol. Rev. 2007, 21, 2-9.

47. Weldon, C.; du Preez, L.H.; Hyatt, A.D.; Muller, R.; Spears, R. Origin of the amphibian chytrid fungus. Emerg. Infect. Dis. 2004, 10, 2100-2105.

48. Cunningham, A.A. A walk on the wild side - emerging wildlife diseases. Br. Med. J. 2005, 331, 1214-1215.

49. Cunningham, A.A.; Daszak, P.; Rodriguez, J.P. Pathogen pollution: defining a parasitological threat to biodiversity conservation. J. Parasitol. 2003, 9, S78-S83.

50. Gaston, K.J.; Fuller, R.A. The sizes of species' geographic ranges. J. Appl. Ecol. 2009, 46, 1-9.

51. Araújo, M.B.; Pearson, R.G. Equilibrium of species' distribution with climate. Ecography 2005, 28, 693-695.

52. Guisan, A.; Zimmermann, N. Predictive habitat distribution models in ecology. Ecol. Model. 2000, 135, 147-186.

53. Blehert, D.S.; Hicks, A.C.; Behr, M.; Meteyer, C.U.; Berlowski-Zier, B.M.; Buckles, E.L.; Coleman, J.T.H.; Darling, S.R.; Niver, R.; Okoniewski, J.C.; Rudd, R.J.; Stone, W.B. Bat white-nose syndrome: An emerging fungal pathogen? Science 2009, 323, 227.

54. Rahbek, C. Disease ecology: the silence of the robins. Nature 2007, 447, 652-653.

55. La Marca, E.; Lips, K.R.; Lötters, S.; Puschendorf, R.; Ibáñez, R.; Rueda-Almonacid, J.V.; Schulte, R.; Marty, C.; Castro, F.; Manzanilla-Puppo, J.; García, J.E.; Bolaños, F.; Chaves, G.; Pounds, J.A.; Toral, E.; Young, B.E. Catastrophic population declines and extinctions in Neotropical harlequin frogs (Bufonidae: Atelopus). Biotropica 2005, 37, 190-201. 
56. Lampo, M.; Rodríguez, A.; La Marca, E.; Daszak, P. A chytridiomycosis epidemic and a severe dry season precede the disappearance of Atelopus species from the Venezuelan Andes. J. Herpetol. 2007, 16, 395-402.

57. Barrionuevo, S.; Mangione, S. Chytridiomycosis in two species of Telmatobius (Anura: Leptodactylidae) from Argentina. Dis. Aquat. Org. 2006, 73, 171-174.

58. Kriger, K.M.; Hero, J.-M. The chytrid fungus Batrachochytrium dendrobatidis is non-randomly distributed across amphibian breeding habitats. Divers. Distrib. 2007, 13, 781-788.

(C) 2009 by the authors; licensee Molecular Diversity Preservation International, Basel, Switzerland. This article is an open-access article distributed under the terms and conditions of the Creative Commons Attribution license (http://creativecommons.org/licenses/by/3.0/). 